\title{
INNOVATIONS OR NOT? \\ - THE IMPACT OF PUBLIC EDUCATION LAWS \\ BETWEEN 1868 AND 1985 \\ ON PEOPLE WITH PHYSICAL DISABILITIES \\ IN HUNGARY
}

\author{
Authors: \\ Renáta Ildikó Hegedűs \\ Eszterházy Károly University \\ Dóra Roszik \\ University of Szeged
}

Első szerző e-mail címe:

hegedusrenataildiko@gmail.com

\section{Lektorok:}

\author{
Pető Bálint (PhD) \\ Szegedi Tudományegyetem \\ Nóbik Attila (PhD, habil.) \\ Szegedi Tudományegyetem \\ és további két anonim lektor...
}

\begin{abstract}
Absztrakt
INNOVACIÓK VAGY SEM? - 1868 ÉS 1985 KÖZÖTTI KÖZOKTATÁSI TÖRVÉNYEK HATÁSA A TESTI FOGYATÉKOSSAGGAL ÉLÖKRE $M A G Y A R O R S Z A G O N$.

Jelen tanulmányunk célja, hogy bemutatásra kerüljenek az 1868 és 1985 közötti Magyarországon bevezetésre kerülő közoktatási törvények, melyek különböző szinten, de az egymásra épülő iskolák rendszerét szabályozták. Továbbá célkitűzésünk, hogy bemutassuk ezek hatását a testi fogyatékossággal élőkre vonatkozóan.
\end{abstract}

Kulcsszavak: innováció, testi fogyatékosság, közoktatási törvények, fogyatékosságtörténet, gyógypedagógia

Diszciplínák: pedagógia, pszichológia

\begin{abstract}
The aim of our present study is to present the public education laws introduced in Hungary between 1868 and 1985, which regulated the system of schools built on different levels but on top of each other. Furthermore, our additional goal is to demonstrate their impact on people with physical disabilities.

Keywords: innovation, physical disability, public education laws, disability history, special education
\end{abstract}

Discipline: psychology, pedagogy 
Hegedűs, Renáta Ildikó \& Roszik, Dóra (2021): Innovations Or Not? - The Impact of Public Education Laws Between 1868 and 1985 on People with Physical Disabilities in Hungary. OxIPO folyóirat, 2021/2. szám, 59-64. DOI: 10.35405/OXIPO.2021.2.59

In addition to the education and upbringing of typically developing children, public education laws and their innovations have greatly influenced the development of the education and upbringing of various disability groups. The aim of our present study is to present the well-known and comprehensive school laws regulating the system of schools of different levels, but built on each other, from 1868 to 1985 in Hungary. Public education laws enacted at that time had different effects on the typically developing group of children and children belonging to different disability groups. The primary aim of our study is to explore the impact these had on children belonging to the group of people with physical disabilities. We try to explore whether they mediate an innovative approach or rather hinder the extension of education to all children.

\section{Evolution of the definition of physical disability}

The concept of special education first appeared in Hungary in the 1880s and has been used by the profession ever since. At first, even in the period surrounding the development of special education terminology, attention was drawn only to those with conspicuous "disabilities" who were referred to by various adjectives "abnormal", "physically or mentally weak" "suffering from physical, mental or moral degeneration". Based on the sources processed, we can conclude that people with physical disabilities were called "physically degenerated" and "physically weak". The pioneers of special education in Hungary -József O. Vértes, Zoltán Tóth and Gusztáv Bárczi - also dealt with the issue of physical disability. In his work entitled General Special Education, published in 1933, Tóth classified people with physical disabilities into the group of special individuals into the 4th subgroup of main group II who were distinguished for their special physical and mental shape and were often referred to as "crippled".In the typology of József O. Vértes, the concepts of normality and abnormality appeared. In his work published in 1940, this group includes the phenotypes of physically abnormal people (cripples), but within this he distinguishes five different types. According to Bárczi, "the task of special education (defectology) is to take care of, educate, raise and employ those who 
belong to its responsibility. People with such defects are those with cognitive, hearing, visual, speech and mobility impairments" (Bárczi, 1959, p. 5). Based on this, it is clear that a "milder" term has emerged that may not be as pejorative as its predecessors. However, these terms are all elements of a larger collective concept/system. In the 20th century, two levels arose in the development of the collective concept of "disability". One of the main groups included people with reduced mobility. We considered it necessary to present the process of the development of these concepts because these were considered to be technical terms of the examined period. Today's definition is as follows:

According to the definition of Section 4, Clause 13 of Act CXC of 2011 on National Public Education, students with special educational needs are among the children and students with special attention, including those with special treatment. Those in need of special attention are:

a) children or students with special needs:

a) children or students with individual needs,

ab) children or students with adaptation, learning and behavior problems,

ac) bighly talented children or students

Based on this, children with physical disabilities also fall into this category.

The Institution on Educational Research and Development (2009) determines handicapped people as the following: people with permanent and irreversible change in their motor and posture functions. This change can occur after an injury, or these functions can absent from birth. Although the Act on Public Education does not use the term "handicapped" but physical disability (Net1).

\section{Public education laws \\ and their impact on people with physical disabilities}

Public education laws have greatly influenced the development of education and training of various disability groups. Below we examine the sections on disability through a presentation of disability laws. The first Act on Folk Education - Article No. XXXVIII of 1868 on Public Education in Folk High Schools - is one of the outstanding merits of Minister József baron Eötvös on compulsory education. Based on this, it requires everyday elementary school for every child between the ages of 6 and 15 . However, the law excludes children with disabilities, including children with physical disabilities. \2. Children who are physically or mentally weak according to the medical officer may be exempted from the obligation to attend school for a shorter or longer period of time by the school board (Section 117).

It brings an amendment to Act No. XXX of 1921 and 130.700. VII VKM Implementing Instruction of 1922. The 
Public Education Act serves to strengthen compulsory education and covers people with disabilities. This law is decisive in the history of Hungarian special education. It strives to achieve the schooling of all school-age children applying punitive rigor if necessary. The law explicitly states that the education of people with disabilities should be segregated as $\int 7$ of the law excludes it from public schools.

"s 7. On the proposal of the teaching staff (teacher) and on the recommendation of the primary school authority (guardianship, school board), the assigned school supervisor excludes the child from the public school for a longer or shorter period of time than it is necessary, if he or she: 1) has an failing in the physical organism that makes normal progress in his or her studies impossible; 2) suffers from a contagious or disgusting disease; 3) is mentally ill or dull-minded; 4) endangers the morals of other children. Children excluded from public school remain obliged to attend school, and the Minister of Religion and Public Education, in agreement with the ministers concerned, regulates the issue of their education in a decree."

However, the last section of $\int 7$ obliges the Minister of Religion and Public Education to regulate the compulsory schooling of the excluded children. Based on this, we can say that this is the first compulsory education for all school-age children. In addition to $₫ 7, \int 6$ also contains a measure to this effect.

$\int 6$. On the proposal of the teaching staff (teacher) ( $(1)$ and on the recommendation of the primary school authority (guardianship, school board), the assigned school supervisor may exempt the child from attending public school if he or she: 1) receives an appropriate education at home or in a private institution; 2) physically or mentally retarded; or if 3) going to school endangers the health or safety of the child. However, a child taught at home or in a private institution is required to take an examination in a public school each year. The rate used in this study should not be lower than the rate set for regular students. If the examination reveals that the education was unsatisfactory, the primary school authority obliges the child's legal guardian to enroll and admit the child to a public school. The education of children belonging to points 2 and 3 is regulated by the decree of the Minister of Religion and Public Education.“

The Act No. III of 1961 is about the Education System of the Hungarian People's Republic. It decides about the school rights of children with disabilities in $\int 4$.

"s 4. In justified cases, the child who is subject to compulsory full- 
time schooling may be exempted from attending school for one school year. The education and upbringing of a physically, sensory or intellectually disabled child who can be trained in compulsory education takes place in special education institutions. An unteachable child should be exempted from attending schools."

This law also includes the notion of "unteachable" that is no longer accepted in the profession. Instead of this, the notion of "unteachability" in the context of school was born.

Act No. I of 1985 on Education states in sections 3 and 4 the right to education and compulsory schooling of all schoolage children. Furthermore, it supports the provision of social equality and the education of people with disabilities In Section 9 Chapter I, among the principles, we can find the following:

"s 9. (1) In order to promote social equality, the state shall provide support to the disadvantaged. (2) The state helps to develop the skills and knowledge of young people with outstanding talent. (3) The state provides increased care about the education of children with physical, sensory, cognitive and speech disability."
The possibility of integrated education arises in the part of Chapter I of the Act on compulsory education. In \52, “(2) A child with a physical, sensory, cognitive or speech disability, whose health and personality condition justifies his or her upbringing and education in a primary school corresponding to his or her disability, fulfills his or her compulsory education in the designated primary school in accordance with the provisions of special legislation."

In addition, "S 75. (2) In the case of students with physical, sensory, cognitive or speech disability, secondary schools also must take into account the nature and extent of the disability."

\section{Summary}

In summary, we can say that disability — in this case, physical disability — and its concept were not new even at the time of the development of special education typology. The different adjectives transformed, shifting towards a less pejorative direction over time. However, we had to wait for the laws on people with physical disabilities to come into force and be applied. The aim of our study is primarily to raise further research questions. For example, whether we can see regulations that do not guarantee the right to education as an innovation or not. That is, they either exempt children from attending school for a shorter or longer period of time or even completely 
exclude some children who are not typically developing for some reason.

\section{References}

Act No. CXC of 2011 on National Public Education

Act No. I of 1985 on Education

Act No. III of 1961 on the Education System of the Hungarian People's Republic

Act No. XXX of 1921 and 130.700. VII VKM Implementing Instruction of 1922

Act No. XXXVIII of 1868 on the subject of public education in folk high schools
Bárczi, G. (1959): Altalános gyógypedagógia. Tankönyvkiadó, Budapest.

Net1: Sajátos nevelési igény: A látássérülés, a ballássérülés, a mozgáskorlátozottság, az. autizmus, a beszédfogyatékosság, az értelmi fogyatékosság.: Ami a kategóriák mögött van. Az Oktatáskutató és Fejlesztő Intézet (OFI) oldalán 2009.06.17-ikén közzétett bejegyzés. Letöltés: 2021.03.20. Web: http://ofi.hu/ sajatos-nevelesi-igeny-latasseruleshallasserules-mozgaskorlatozottsag-azautizmus Downloaded: 29 Oct 2019

Tóth, Z. (1933). Általános gyógypedagógia. Magyar Gyógypedagógiai Társaság, Budapest.

Vértes, O. J. (1940): A gyógyitó nevelés rendszere. Kókai, Budapest. 